\title{
ЭКОНОМИКА
}

ECONOMY

УДК 330.567.4:796.032.2(520)

DOI dx.doi.org/10.24866/1813-3274/2020-2/15-29

М. Е. Комаров ${ }^{1}$, Институт стран Азии и Африки Московского

государственного университета им. М. В. Ломоносова, г. Москва, Россия

E-mail:komarovmikh@gmail.com

\section{ОРГАНИЗАЦИЯ ОЛИМПИЙСКИХ ИГР: АНАЛИЗ СТРУКТУРЫ РАСХОДОВ НА ПРЕДОЛИМПИЙСКОМ ЭТАПЕ НА ПРИМЕРЕ ЯПОНИИ}

Аннотация. В данной статье рассматривается актуальный вопрос расходов на организацию летних Олимпийских игр на предолимпийском этапе. В статье проводится анализ структуры расходов на рассматриваемом этапе на примере XXXII летних Олимпийских игр в Токио. Детально исследуется структура расходов на двух крупных подэтапах: подача заявки на проведение Игр и непосредственно организация Олимпиады, при этом отдельно выделяются расходы трёх основных групп: Международного олимпийского комитета (с фокусом на программе Олимпийской солидарности), условной группы бизнеса и условной группы государства. На первом подэтапе в условную группу государства входят Токийский муниципалитет, правительство Японии и Заявочный комитет Токио 2020, в то время как на втором рассматриваемом подэтапе место Заявочного комитета занимает учреждённый в 2014 г. после официального избрания Токио городом-организатором Организационный комитет Токио 2020. В рамках каждой из трёх основных групп приводятся конкретные проекты, проводится анализ статей расходов на их осуществление. Отдельно стоит выделить тот факт, что автор, являясь действующим сотрудником Организационного комитета Токио 2020, осуществляет детальное изучение проектов и статей расходов, зачастую не попадающих в поле зрения исследовате-

\footnotetext{
${ }^{1}$ Михаил Евгеньевич Комаров, аспирант кафедры экономики и экономической географии стран Азии и Африки Института стран Азии и Африки Московского государственного университета им. М. В. Ломоносова, г. Москва, Россия.

Для циттирования: Комаров М. Е. Организация Олимпийских игр: анализ структуры расходов на предолимпийском этапе на примере Японии // Азиатско-Тихоокеанский регион: экономика, политика, право. 2020. № 2. С. 15-29.

(C) Комаров М. Е., 2020
} 
лей данной темы. Отдельно анализируются факторы и причины увеличения первоначального бюджета на организацию и проведение XXXII летних Олимпийских игр, в частности такие, как перенос соревнований по марафону и спортивной ходьбе из Токио в г. Саппоро, перенос Игр на 2021 г. в связи с угрозой распространения вируса COVID-19 и т.д. На основе имеющихся данных по состоянию на май 2020 г. выделяется ряд тенденций, связанных со статьями расходов отдельно взятых групп. Основываясь на данных проведённого исследования, автор делает вывод, что наибольшие расходы на предолимпийском этапе несёт условная группа государства, в рамках которой доли Токийского муниципалитета и Оргкомитета Токио 2020 условно равны.

Ключевые слова: Олимпийские игры, Организационный комитет Токио 2020, структура расходов Олимпийских игр, Токийский муниципалитет, Заявочный комитет Токио 2020, Международный олимпийский комитет, экономика Олимпийских игр, предолимпийский этап, XXXII летние Олимпийские игры, программа Олимпийской солидарности.

Mikhail E. Komarov ${ }^{1}$, The Institute of Asian and African Countries, Lomonosov Moscow State University, Moscow, Russia

E-mail: komarovmikh@gmail.com

\section{STAGING THE OLYMPIC GAMES: ANALYSIS OF THE COST STRUCTURE AT THE PRE-OLYMPIC STAGE ON THE EXAMPLE OF JAPAN}

Abstract. This article deals with the topical issue of the costs related to hosting the Olympic Games at the pre-Olympic stage. The article provides an analysis of the cost structure at this stage on the example of the Games of the XXXII Olympiad in Tokyo. The cost structure in two major sub-stages is studied in detail: bidding stage and the organizing stage, with the focus on the costs of three main groups: the International Olympic Committee (highlighting the Olympic Solidarity program), nominal business group and nominal state group. In the first sub-stage the nominal state group includes Tokyo Metropolitan Government, the government of Japan and the Tokyo 2020 Bidding Committee, while in the second sub-stage the Tokyo 2020 Bidding Committee is replaced by the Tokyo 2020 Organising Committee, established in 2014 after Tokyo was officially elected as the host city. Specific examples of the projects within each of the three main

\footnotetext{
${ }^{1}$ Mikhail E. Komarov, Postgraduate student of the Department of Economics and Economic Geography of Asian and African Countries, Institute of Asian and African Countries, Lomonosov Moscow State University, Moscow, Russia.

For citing: Komarov M. E. Staging the Olympic Games: analysis of the cost structure at the pre-Olympic stage on the example of Japan // PACIFIC RIM: Economics, Politics, Law. 2020. No 2. P. 15-29.
} 
groups are indicated and the analysis of the costs related to their implementation is conducted. It is important to highlight the fact, that the author of the article, being the current employee of the Tokyo 2020 Organising Committee, has carried out a detailed study of projects and cost items that frequently are not covered by other researchers of this issue. The factors and reasons for increased budget, compared with the initial one, for staging and holding the Games of the XXXII Olympiad are analyzed separately; particular emphasis has been put on the transfer of the marathon and race walk competition from Tokyo to Sapporo city and on the postponement of the Games till 2021 due to the threat of the COVID-19 virus spread, etc. Based on the available data as of May 2020, a number of trends related to the cost items of the main groups are indicated. Based on the materials of this article the author concludes that the largest expenses at the pre-Olympic stage are borne by the nominal group of state, within which the shares of Tokyo Metropolitan Government and the Tokyo 2020 Organising Committee are conditionally equal.

Keywords: Olympic Games, the Tokyo 2020 Organising Committee, Olympic Games cost structure, Tokyo Metropolitan Government, the Tokyo 2020 Bidding Committee, the International Olympic Committee, the economics of the Olympic Games, preOlympic stage, the Games of the XXXII Olympiad, Olympic Solidarity program.

Олимпийские игры являются крупнейшим событием в мире спорта, оказывающим влияние на экономику не только основного города-организатора, но и всей страны-хозяйки Игр в целом. Общеизвестным фактом является то, что количество спортсменов на современных летних Олимпийских играх неизменно превышает 10 тыс. человек. Кроме того, зачастую в программу каждой следующей Олимпиады включаются новые дисциплины, что в свою очередь увеличивает количество участников в арифметической прогрессии. Несмотря на то, что, безусловно, центральными фигурами Олимпийских игр являются именно спортсмены, важно отметить, что во многих дисциплинах их выступление невозможно без персональных тренеров, спарринг-партнёров, медицинского и административного персонала (руководителей спортивных делегаций - Chef de Mission), президентов и генеральных секретарей национальных олимпийских комитетов (НОК), менеджеров команд, механиков, конюхов и т.д.). Таким образом, количество участников летних Олимпиад превышает отметку в десятки тысяч человек.

Нельзя не отметить и большое количество участников со стороны организаторов Игр. В их число входят представители Организационного комитета Олимпийских игр, Международного олимпийского комитета (МОК), третьих сторон, оказывающих всевозможные услуги, сотрудники местной власти, полиции, медицинских учреждений, пожарной безопасности, волонтёры, спонсоры, теле- и радиовещатели и т.д. Трудоёмкий процесс организации и проведения Олимпийских игр, 
включающий в себя в том числе и координацию взаимодействия всех вышеупомянутых участников, обусловливает возникновение крупных финансовых расходов в рамках каждой Олимпиады.

\section{Актуальность вопроса расходов Олимпийских игр на предолимпийском этапе}

Тема расходов на подготовку и проведение Олимпиад не теряет своей актуальности в последние десятилетия. На эту тему написан ряд отечественных и зарубежных исследований и научных трудов, целью которых является не только изучение расходов Олимпийских игр, но и влияние Олимпиад на экономику страныорганизатора в целом. Однако, во-первых, организация и проведение каждых отдельных Игр имеют свои характерные особенности и отличия. Во-вторых, зачастую расходы, связанные с Олимпийскими играми, ассоциируются именно с расходами на олимпийском этапе, вследствие чего многие исследования теряют свою комплексность. В данной статье подробно рассмотрена структура расходов на подготовку Олимпиад на предолимпийском этапе на примере летних Олимпийских игр в Токио в 2021 г. (Токио 2020) ${ }^{1}$.

На текущем этапе научных работ на тему расходов Токио 2020 на предолимпийском этапе практически не написано ни в России, ни за рубежом. Между тем, анализ структуры расходов на предолимпийском этапе является одним из ключевых моментов в принятии решения страны о подаче заявки на проведение Олимпиады на своей территории. Следовательно, данная работа несёт практическую ценность не только для исследователей экономики Олимпийских игр, но и для членов Организационных комитетов будущих Игр; также она может являться подспорьем для представителей городов-кандидатов и заявочных комитетов на этапе планирования подачи заявки на проведение Игр.

При изучении многих тем, связанных с экономикой Олимпийских игр, включая и расходы на организацию и проведение Олимпиад, нельзя не обратиться к работам всемирно признанного исследователя экономики Олимпийских игр Х. Пройca (H. Preuss), а также отечественного исследователя Р. М. Нуреева. Однако, при всей детальности и многогранности их исследований, а также при глубоком уважении к их труду указанные исследователи не являлись непосредственными сотрудниками ни одного из Организационных комитетов Игр, в связи с чем определённые детали в структуре расходов не отражены в опубликованных ими исследованиях.

\footnotetext{
${ }^{1} 30$ марта 2020 г. Организационный комитет Токио 2020 объявил о принятом совместно с МОК и Премьер-министром Японии С. Абэ решении о переносе XXXII летних Олимпийских Игр с 2020 г. на 2021 г. в связи с угрозой распространения новой коронавирусной инфекции COVID-19. Несмотря на это, было решено оставить официальное название Олимпийских игр в Токио прежним (Токио-2020). Прим. авт.
} 
Автор данной работы, в свою очередь, является действующим сотрудником Организационного комитета летних Олимпийских и Паралимпийских игр Токио 2020 (Оргкомитет Токио 2020), что даёт ему доступ к большему количеству источников, к более глубокому пониманию рабочих процессов в рамках подготовки и проведения Олимпийских игр и, соответственно, позволяет провести более комплексный анализ структуры расходов.

\section{Расходы на различных этапах олимпийского цикла}

Организация и проведение современных Олимпийских игр - долгосрочный и крайне трудоёмкий процесс, занимающий в среднем 8-9 лет. Так, например, официальные заявки на проведение XXXII летних Олимпийских игр были поданы городами-кандидатами до 1 сентября 2011 г., исходя из чего можно сделать вывод, что подготовка к проведению Игр в Токио началась более чем за 9 лет до церемонии открытия (10 лет с учётом переноса Игр на 2021 г.). В свою очередь, Организационный комитет Олимпийских и Паралимпийских игр Токио 2020 был учреждён 24 января 2014 г. Таким образом, становится очевидно, что расходы, связанные с Олимпийскими играми, далеко не ограничиваются непосредственно этапом их проведения.

Согласно классификации олимпийского цикла, которую используют такие исследователи, как Р. М. Нуреев и Е. В. Маркин [1, с. 88], расходы на организацию и проведение Олимпийских игр можно условно разделить на три этапа: расходы на предолимпийском, олимпийском и постолимпийском этапах. Продолжительность каждого этапа и структура расходов в рамках конкретного этапа кардинально отличаются. В данной работе будет предоставлен подробный анализ первого из трёх этапов.

Предолимпийский этап: начало деятельности комиссии по подготовке заявки города-кандидата (заявочного комитета) - 30 дней до церемонии открытия Олимпийских игр (2011 г. - июнь 2021 г. для Токио 2020);

Олимпийский этап: 30 дней до церемонии открытия Олимпийских игр 30 дней после церемонии закрытия (июнь - сентябрь 2021 г. для Токио 2020);

Постолимпийский этап: 30 дней после церемонии закрытия Игр - окончание следующего летнего туристического сезона (сентябрь 2021 г. - сентябрь 2022 г. для Токио 2020) [1, с. 88].

Перед тем, как приступить к анализу структуры расходов на организацию Олимпийских игр в Токио в 2021 г. на предолимпийском этапе, важно также отметить, что расходы приходятся на долю нескольких сторон: МОК, страныорганизатора (условную группу государства) и условную группу бизнеса. Кроме того, расходы не делятся поровну на количество сторон, а также их размер отличается на каждом из двух рассматриваемых подэтапов, в связи с чем в рамках данного 
исследования крайне важно провести анализ расходов отдельно взятых сторон для более глубокого понимания структуры расходов Олимпийских игр в целом.

\section{Подэтап подачи заявки}

Согласно классификации олимпийского цикла, предолимпийский этап является самым продолжительным. За счёт переноса Олимпийских игр на 2021 г. предолимпийский этап Токио 2020 растянулся более чем на 10 лет, что, безусловно, является одним из самых продолжительных показателей в истории Игр. В связи с этим, можно выделить два крупных подэтапа: подача заявки и непосредственная подготовка к проведению Олимпиады.

Подэтап подачи заявки включает в себя следующие виды издержек государства: подготовка документов для подачи заявки, оплата членского взноса в адрес Международного олимпийского комитета за рассмотрение заявки, подготовка и проведение мероприятий по популяризации Олимпийских игр среди местного населения, реклама страны-организатора, развитие инфраструктуры, подготовка к визиту оценочной комиссии МОК и т.д. Суммарные расходы государства в рамках подэтапа подачи заявки составили 8,9 млрд иен (83,4 млн долл. $\left.{ }^{1}\right)$, из них 3,5 млрд иен (32,8 млн долл.) было затрачено из бюджета Токийского муниципалитета, а остальные 5,4 млрд иен (50,6 млн долл.) - из бюджета Заявочного комитета Токио 2020 [8, с. 225]. Отдельные статьи расходов Японии в рамках подэтапа подачи заявки отражены в табл. 1.

Стоит отдельно отметить, что Токио также выставлял свою кандидатуру на проведение летних Олимпийских игр 2016 г., однако во втором раунде голосования проиграл Мадриду и Рио-де-Жанейро. Общая сумма затрат на подэтапе подачи заявки на проведение Игр 2016 г. составила около 14,9 млрд иен (139,6 млн долл.). Безусловно, данные расходы было бы неверно включить в структуру расходов летней Олимпиады 2021 г., однако важно подчеркнуть тот факт, что затраты на заявочную кампанию Токио 2020 были более чем на 40\% ниже расходов на кампанию 2016 г. именно благодаря тому, что ответственные за заявку и подготовку необходимых материалов лица сделали выводы из проигранной кампании 2016 г., а также использовали в заявке Токио-2020 ряд решений и материалов, подготовленных за счёт финансирования предыдущей заявки. Таким образом, несмотря на то, что при составлении статистических данных о расходах на подэтапе подачи заявки на проведение XXXII летней Олимпиады затраченные на заявочную кампанию 2016 г. 139,6 млн долл. не учитываются, в рамках данной работы необходимо подчеркнуть значительную важность данных расходов.

\footnotetext{
${ }^{1}$ По курсу ЦБ Японии на 18.05.2020. Прим. авт.
} 
Статьи расходов Японии как страны-организатора Олимпийских игр Токио 2020 на подэтапе подачи заявки, млн долл.

\begin{tabular}{|l|l|l|l|l|l|}
\hline \multicolumn{2}{|c|}{} & \multicolumn{2}{c|}{$\begin{array}{c}\text { Расходы Токийского } \\
\text { муниципалитета }\end{array}$} & \multicolumn{2}{c|}{ Расходы } \\
Заявочного комитета
\end{tabular}

Составлено автором по: [8, с. 225]

Что касается условной группы бизнеса, то она принимала долевое участие в мероприятиях Заявочного комитета Токио 2020. Так, например, крупнейший японский рекламно-коммуникационный холдинг Dentsu Incorporated (Dentsu) принимал непосредственное участие в осуществлении пиар-кампании для поднятия престижа проведения Игр в Японии. Dentsu контролирует около 25\% домашнего рынка всевозможной рекламной продукции, в связи с чем поддержка данного холдинга начала играть важную роль уже на подэтапе подачи заявки на проведение Игр Токио 2020. Среди мер в рамках данной пиар-кампании можно выделить создание оригинальных рекламных плакатов и баннеров, телевизионных роликов, радиорекламы и т.д. Кроме того, важно отметить, что среди крупнейших клиентов Dentsu присутствует немало официальных партнёров XXXII летних Олимпийских игр, таких как всемирно известный автомобильный гигант Toyota и один из крупнейших в мире производителей электроники и бытовой техники Panasonic. Тесное сотрудничество Dentsu c партнёрами такого рода - своеобразный ключ к увеличению уровня поддержки идеи проведения Игр среди населения Японии. Среди других крупнейших представителей бизнеса, оказывавших поддержку Японии в качестве страныкандидата на право проведение Игр 2020 г., можно также выделить широко известного производителя часов Seiko Watch, телекоммуникационный холдинг SoftBank, ведущего производителя напитков Asahi Breweries и т.д. 
Что касается расходов МОК, то важно отметить, что в 2014 г. на сессии МОК был утверждён новый формат заявочного процесса городов-кандидатов. Согласно новому формату, МОК снимает с городов-организаторов и покрывает за свой счёт следующие финансовые затраты: организация и проведение визита оценочной комиссии, перелёт и проживание 6 представителей каждого заявочного комитета в рамках официального визита в штаб-квартиру МОК в Лозанне, в рамках сессии Ассоциации летних олимпийских международных федераций (ASOIF), а также сессии Ассоциации национальных олимпийских комитетов (ANOC) для проведения презентации города-кандидата, перелёт и проживание 12 членов заявочного комитета каждого города-кандидата для участия в сессии МОК, на которой проводится финальное голосование за право проведения Игр, публикация файла заявки в электронном виде и т.д. [3, с. 11].

Однако, учитывая то, что Токио был выбран городом-организатором летних Олимпийских Игр в 2013 г., отмеченные выше финансовые затраты были полностью покрыты за счёт государства в лице Токийского муниципалитета и Заявочного комитета. Соответственно, МОК до 2014 г. не нёс никаких финансовых затрат, напрямую связанных с процессом подготовки и подачи заявки города-кандидата Токио. Безусловно, затраты на проведение соответствующих семинаров, сессий и презентаций покрываются за счёт МОК, однако они непосредственно связаны в том числе и с подачей заявок других городов-кандидатов, а также проведением плановых организационных мероприятий, в связи с чем было бы неверно включать подобные расходы в структуру расходов на подготовку и проведение Олимпийских игр в Токио.

Таким образом, наибольшие затраты на подэтапе подачи заявки берёт на себя условная группа государства, так как именно оно занимается формированием заявочного комитета, разработкой и утверждением файла города-кандидата, проведением пиар-компаний совместно с бизнесом и т.д.

\section{Подэтап подготовки к проведению Олимпийских игр}

На текущий момент Токио находится на втором подэтапе предолимпийского цикла, который длится уже более 7 лет (2013-2020 гг.) и который, безусловно, связан со значительно более крупными затратами. Среди государственных расходов на текущем этапе можно выделить следующие: административные (поиск и обучение волонтёров), расходы на организацию и проведение церемоний открытия и закрытия Игр, церемоний награждения, эстафеты Олимпийского огня, создание материально-технической базы (строительство и оборудование Олимпийской деревни в районе Харуми, переоборудование Международного Выставочного Центра Токио в Международный телерадиовещательный центр и пресс-центр, строительство временных спортивных объектов и реконструкция существующих), развитие инфра- 
структуры (переоборудование станций метро для обеспечения стопроцентной доступности для всех категорий болельщиков и спортсменов, усовершенствование систем связи, строительство дорог), защита окружающей среды и т.д. Отдельные расходы условной группы государства (Токийского муниципалитета, Оргкомитета и расходы непосредственно из государственного бюджета) подробно рассмотрены в табл. 2.

Таблицча 2

Общая структура бюджета на организацию Олимпийских игр Токио 2020 в рамках условной группы государства, 2019 г., млрд долл.

\begin{tabular}{|c|c|c|c|c|c|}
\hline \multicolumn{2}{|c|}{ Статья расходов } & $\begin{array}{l}\text { Оргко- } \\
\text { митет }\end{array}$ & $\begin{array}{c}\text { Муници- } \\
\text { палитет } \\
\text { Токио }\end{array}$ & $\begin{array}{c}\text { Гос. бюд- } \\
\text { жет }\end{array}$ & $\begin{array}{c}\text { Сумма } \\
\text { расходов } \\
\text { по отдель- } \\
\text { ным } \\
\text { статьям }\end{array}$ \\
\hline \multirow{3}{*}{$\begin{array}{l}\text { Сооружения } \\
\text { и объекты }\end{array}$} & Существующие & - & 2,1 & 1,1 & 3,2 \\
\hline & $\begin{array}{l}\text { Постройка } \\
\text { временных / } \\
\text { модернизация }\end{array}$ & 0,9 & 1,9 & \multirow{2}{*}{0,2} & \multirow{2}{*}{4,4} \\
\hline & $\begin{array}{l}\text { Электроэнергия } \\
\text { и технологии }\end{array}$ & 0,8 & 0,6 & & \\
\hline \multicolumn{2}{|l|}{ Сервисы } & 3,6 & 0,8 & 0,1 & 4,7 \\
\hline \multicolumn{2}{|c|}{ Дискреционные расходы } & 0,1 & 0,1 & - & 0,2 \\
\hline \multicolumn{2}{|c|}{ Сумма расходов отдельной группы } & 5,4 & 5,5 & 1,4 & 12,6 \\
\hline
\end{tabular}

Составлено автором по: [9]

Безусловно, указанные в табл. 2 статьи расходов необходимо учитывать при анализе структуры затрат на подготовку и проведение Олимпийских игр в Токио, однако стоит отметить, что исследователи, не имеющие опыта непосредственной работы в Оргкомитетах Игр, зачастую упускают из внимания неочевидные на первый взгляд организационные издержки подготовки Токио 2020. Среди подобного рода расходов Оргкомитета можно выделить следующие: меры противодействия жаркому и влажному климату Японии (установка аппаратов для искусственного изготовления снега, например, на объектах проведения соревнований по гребле на каноэ), аренда офисных помещений и офисной аппаратуры для сотрудников, выплата зарплат и пособий контрактным работникам, бизнес-поездки сотрудников, осуществление телефонных звонков в роуминге представителям МОК, СМИ, НОК по всему миру, отправка договоров, визовых документов и аккредитационных карт международной почтой представителям всех 206 НОК и прочим официальным ли- 
цам, аренда площадей в залах прилётов аэропортов и гостиничных помещениях для установки операционных стоек, проведение семинара глав спортивных делегаций (Chef de Mission Seminar), инспекционных туров по объектам, обучающих мероприятий, установка специальных тентов для проведения дистанционного процесса регистрации на обратные рейсы гостей Олимпийской деревни и т.д. Несмотря на то, что удельный вес каждой из статей данных расходов оценить весьма проблематично, так как они заложены в бюджет уже на стадии подачи заявки на право проведения Игр, важно отдельно выделять данные затраты при анализе структуры расходов Олимпиад, так как на них приходится весомая часть бюджета (к примеру, установка специальных тентов в Олимпийской деревне для проведения дистанционной регистрации на рейсы, по оценкам автора, обойдётся в 512 тыс. долл.).

Среди не самых очевидных расходов Токийского муниципалитета можно выделить затраты на брендирование общественного транспорта и общественных мест, командирование сотрудников для работы в Оргкомитете (более 30\% сотрудников Оргкомитета командированы из Токийского муниципалитета), проведение пиармероприятий (500 дней до церемонии открытия Игр, 1 год до церемонии открытия Игр и т.д.), предоставление симуляторов землетрясения совместно с Токийским пожарным управлением в рамках проведения семинара глав спортивных делегаций в Токио и т.д.

На текущем этапе бизнес в Японии сталкивается со следующими издержками: строительство объектов гостиничного бизнеса (гостиница Clad в районе проведения соревнований по шоссейным велогонкам и др.), совершенствование туристической и бизнес-инфраструктуры (перевод меню и инструкций в ресторанах и прочих заведениях на иностранные языки, найм дополнительных сотрудников со знанием иностранных языков) и т.д. Также стоит отметить командирование персонала для работы в Оргкомитете такими крупными компаниями, как Toyota, Japan Tobacco (табачная компания), JAL, ANA (две крупнейшие авиакомпании Японии), предоставление бесплатной сувенирной продукции сотрудникам Оргкомитета, МОК и НОК, демонстрация в рамках семинара глав спортивных делегаций в Токио модели автомобиля Тoyota NOAH, специально разработанной для перевозки малоподвижных категорий граждан во время Игр в Токио, и т.д. Отдельно стоит подчеркнуть дополнительные расходы условной группы бизнеса, вызванные переносом Игр в Токио на 2021 г. в связи с угрозой распространения коронавирусной инфекции. Долгосрочные планы развития большого количества компаний были ориентированы на значительную прибыль, в том числе на предолимпийском этапе, в связи с ростом туристической привлекательности Японии. В то же время дополнительные расходы вызваны простоем гостиниц, критическим падением спроса в сфере развлечений и досуга, а также застоем в туристической сфере, сфере общественного питания и прочих сферах экономики Японии. 
По состоянию на 2019 г. МОК выплатил 0,8 млрд долл. в пользу Оргкомитета для покрытия организационных расходов на подготовку и проведение Токио 2020 [9]. На подэтапе подготовки к проведению XXXII летней Олимпиады МОК берёт на себя в частности следующие расходы в размере 46,7 млн долл. (по состоянию на 2019 г.) [4] в рамках программы Олимпийской солидарности: выплаты индивидуальных Олимпийских грантов для спортсменов в рамках подготовки к Токио 2020 (31 млн долл. выплачен 1,5 тыс. спортсменам), командные гранты (10 млн долл. 189 командам), оплата перелёта и проживания 1 представителя каждого из 206 НОК для участия в семинаре глав спортивных делегаций в Токио, оплата перелёта и проживания 2 представителей каждого НОК для участия в региональных собраниях (к примеру, в собрании Олимпийского совета Азии в Бангкоке в ноябре 2019 г.), 15 тыс. долл. на НОК для организации тренировочных сборов в Японии, субсидии в размере 16 тыс. долл. на НОК для покрытия операционных расходов (униформа, страхование, спортивный инвентарь и т.д.) [4].

Необходимо отдельно отметить тот факт, что, согласно анализу структуры расходов на подэтапе организации Игр, крупнейшие расходы приходятся на долю условной группы государства, при этом доли Оргкомитета и Токийского муниципалитета примерно равны и составляют 5,6 млрд долл. (см. табл. 2).

\section{Увеличение расходов на организацию Токио 2020}

Согласно первоначальному бюджету на подготовку и проведение Олимпийских игр в 2020 г., который был направлен в МОК Заявочным комитетом Токио 2020, суммарные затраты должны были составить 7,3 млрд долл., однако к 2019 г. бюджет уже увеличился на 5,3 млрд долл. и достиг отметки в 12,6 млрд долл. (см. табл. 2). Это увеличение связано, безусловно, в том числе и с не вполне корректными аудиторскими оценками и осознанным занижением бюджета Игр Заявочным комитетом с целью предоставления Токио в наилучшем свете перед анонимным голосованием МОК на выбор города-организатора Игр 2020 г. Однако можно утверждать, что финальные затраты на проведение Игр будут значительно выше. Это связано с двумя факторами.

Во-первых, 16 октября 2019 г. МОК объявил о своём решении о переносе соревнований по марафону и спортивной ходьбе среди женщин и мужчин из Токио в административный центр самой северной префектуры Японии - г. Саппоро. Такое решение было связано с переживаниями представителей международных спортивных федераций и национальных олимпийских комитетов относительно условий проведения данных соревнований на открытом воздухе в жарком влажном климате Токио. Это решение было неожиданным для представителей Оргкомитета и Токийского муниципалитета в связи с тем, что оно было принято без должного согласования с организаторами, а также с тем, что необходимые приготовления для прове- 
дения данных соревнований в Токио уже были на финальной стадии (укладка специального теплоотталкивающего покрытия на маршруте соревнований, установка распылителей воды и т.д.). Кроме того, остро встал вопрос о том, кто будет покрывать расходы, связанные с переносом соревнований в г. Саппоро (модернизация инфраструктуры, расширение штата сотрудников, предоставление различных сервисов и т.д.). Согласно оценкам экспертов, расходы составят около 28 млн долл., однако по состоянию на май 2020 г. финального решения достигнуто не было. МОК, Токийский муниципалитет и Оргкомитет пришли к соглашению, что для покрытия расходов не будут использованы средства Токийского муниципалитета или же средства из бюджета префектуры Хоккайдо. Согласно промежуточным итогам переговоров МОК и Оргкомитета Токио 2020 в апреле 2020 г., МОК покроет около $65 \%$ расходов (18,7 млн долл.) [6], включая расходы на размещение спортсменов и представителей команд, а остальная часть расходов будет покрыта за счёт бюджета на непредвиденные расходы Оргкомитета, равного 0,3 млрд долл. [9].

Вторым фактором, оказывающим беспрецедентное влияние на увеличение расходов Токио 2020, безусловно, является перенос XXXII летних Олимпийских игр на 2021 г. в связи с угрозой распространения новой коронавирусной инфекции COVID-19. Согласно оценкам экспертов, результатом переноса Игр в Токио могут стать дополнительные расходы в размере от 3 до 6 млрд долл. Оценки разнятся в связи с тем, что по состоянию на май 2020 г. переговоры со спортивными объектами, объектами размещения, включая Олимпийскую деревню, не завершены, вследствие чего не ясно, будут ли использованы все те же самые объекты для проведения соревнований в 2021 г. Что касается Олимпийской деревни, то ситуация осложняется тем, что на момент официального объявления решения о переносе Игр часть квартир уже была продана частным лицам для использования после окончания Игр.

Несмотря на это, МОК уже объявил, что выделит дополнительные 800 млн долл. в связи с переносом Олимпийских игр в Токио на 2021 г., 650 млн долл. из которых будут потрачены непосредственно на организацию Игр, а остальные средства - на финансовую поддержку международных спортивных федераций и НОК [2]. Кроме того, в рамках программы Олимпийской солидарности будут дополнительно выделены 25,3 млн долл. на поддержку деятельности НОК [5].

МОК заявляет, что остальные расходы, связанные с переносом Игр, должны быть покрыты условной группой государства согласно контракту с городоморганизатором Олимпийских игр, заключённому между МОК, Токийским муниципалитетом и Олимпийским комитетом Японии 7 сентября 2013 г. Однако по состоянию на май 2020 г. соглашение между японской стороной и МОК достигнуто не было, как и в случае с переносом соревнований по марафону и спортивной ходьбе в г. Саппоро.

Таким образом, становится очевидно, что затраты на предолимпийском этапе являются значимой статьёй расходов на подготовку и проведение Олимпийских 
игр. Согласно общепринятой классификации олимпийского цикла, расходы предолимпийского этапа можно разделить на два крупных подэтапа: подача заявки и организация Игр. Анализ статей расходов на данных подэтапах позволил заключить, что наибольшие расходы приходятся на условную группу государства. Отдельно стоит отметить увеличение расходов на подготовку Олимпийских игр в Токио в связи с рядом факторов: оптимистичные аудиторские оценки на стадии подачи заявки, перенос соревнований по марафону и спортивной ходьбе в г. Саппоро и, безусловно, перенос Игр на 2021 г. в связи с угрозой распространения вируса COVID-19. По состоянию на май 2020 г. нельзя дать абсолютно точных оценок дополнительных расходов, вызванных указанными факторами, однако представляется возможным выделение некоторых тенденций в области издержек на предолимпийском этапе (оплата большей части расходов, связанных с переносом соревнований в г. Саппоро, за счёт МОК, увеличение объёма финансовой поддержки НОК в рамках программы Олимпийской солидарности и т.д.). Безусловно, анализ структуры расходов на олимпийском и постолимпийском этапах является не менее актуальным и важным, вследствие чего такого рода анализ будет продолжен в дальнейших исследованиях.

\section{Список литературы}

1. Нуреев, Р. М., Маркин, Е. В. Издержки и выгоды Олимпийских игр // Общественные науки и современность. - 2010. - № 1. - С. 88-104. - URL: https://economics.hse.ru/data/2012/10/01/1243828961/\%D0\%98\%D0\%97\%D0\%9 4\%D0\%95\%D0\%A0\%D0\%96\%D0\%9A\%D0\%98\%20\%D0\%98\%20\%D0\%92\%D 0\%AB\%D0\%93\%D0\%9E\%D0\%94\%D0\%AB\%20\%D0\%9E\%D0\%9B\%D0\%98\% D0\%9C\%D0\%9F\%D0\%98\%D0\%99\%D0\%A1\%D0\%9A\%D0\%98\%D0\%A5\%20 \%D0\%98\%D0\%93\%D0\%A0.pdf (дата обращения: 07.04.2020).

2. Inside the Games. Postponement of Tokyo 2020 Olympics to cost IOC $\$ 800$ million // 14.05.2020. - URL: https://www.insidethegames.biz/articles/1094252/iocannounce-tokyo-2020-cost-800-million (дата обращения: 15.05.2020). (In English).

3. International Olympic Committee. Olympic Agenda 2020. Implementation plan - 2016 and beyond // 110 P. - URL: https://stillmed.olympic.org/media/Document \%20Library/OlympicOrg/Documents/Olympic-Agenda-2020/Olympic-Agenda-2020 Implementation-Plan-2016-and-Beyond.pdf\#_ga=2.129246156.1907296350. 1588568592-1444275578.1581867662 (дата обращения: 02.05.2020). (In English).

4. International Olympic Committee. Olympic Solidarity // URL: https://www.o lympic.org/olympic-solidarity (дата обращения: 06.05.2020). (In English). 
5. International Olympic Committee. Olympic Solidarity increases its support to National Olympic Committees for their preparation for and participation in Tokyo 2020 by USD 25.3 million // 24.04.2020. - URL: https://www.olympic.org/news/olympic-solidarityincreases-its-support-to-national-olympic-committees-for-their-preparation-for-andparticipation-in-tokyo-2020-by-usd-25-3-million (дата обращения: 05.04.2020). (In English).

6. Kyodo News. 札瑺経費、IOCが部負担へ(MOK возьмёт на себя часть расходов на перенос соревнований в г. Саппоро) // 25.04.2020. - URL: https://this.ki ji.is/626463063497868385 (дата обращения: 11.05.2020). (In Japanese).

7. Sakata, W. オリンピックと経済 (2020年東京オリンピック・パラリンピック競支大会に 向けた諸柦題) (Олимпийские игры и экономика (проблемы проведения Олимпийских и Паралимпийских игр в Токио в 2020 г.)). - DOI: 10.11501/9880033 // 国六国会図書㝗 (Библиотека парламента Японии). - 2016. - № 2. - P. 17-41. - URL: https://dl.ndl.go.jp/view/download/digidepo_9880033_po_078103.pdf?contentNo= 1\&alternativeNo= (дата обращения: 04.05.2020). (In Japanese).

8. Tokyo 2020 Bidding Committee. 2020年オリンピック・パラリンピック競支大会招 致活動報告書 (Отчёт о деятельности Заявочного комитета в рамках Олимпийских и Паралимпийских игр 2020 г.) // апрель 2014. - 322 P. - URL: https:/www.202 0games.metro.tokyo.lg.jp/taikaijyunbi/torikumi/syochi/pdf/syochihokokusyoall.pdf (дата обращения: 10.04.2020). (In Japanese).

9. Tokyo 2020 Organising Committee of the Olympic and Paralympic Games. 組織委員会およびその他の経費 (V4予算) (Бюджет Организационного комитета и других организаций (4-я версия бюджета)) // 20.12.2019. - URL: https://tokyo2020.org/ ja/organising-committee/budgets/ (дата обращения: 18.04.2020). (In Japanese).

\section{References}

1. Nureev, R. M., Markin, E. V. Costs and benefits of the Olympic Games // Obschestvennie nauki i sovremennost [Social sciences and modernity]. - 2010. - Vol. 1. - P. 88-104. - URL: https:/economics.hse.ru/data/2012/10/01/1243828961/\%D0\%98\%D0\%97\%D0\%94\%D0 $\% 95 \%$ D0\%A0\%D0\%96\%D0\%9A \%D0\%98\%20\%D0\%98\%20\%D0\%92\%D0\%AB\%D0 $\% 93 \% \mathrm{D} 0 \% 9 \mathrm{E} \% \mathrm{D} 0 \% 94 \% \mathrm{D} 0 \% \mathrm{AB} \% 20 \% \mathrm{D} 0 \% 9 \mathrm{E} \% \mathrm{D} 0 \% 9 \mathrm{~B} \% \mathrm{D} 0 \% 98 \% \mathrm{D} 0 \% 9 \mathrm{C} \% \mathrm{D} 0 \% 9 \mathrm{~F}$ $\%$ D0\%98\%D0\%99\%D0\%A $1 \%$ D0\%9A\%D0\%98\%D0\%A5\%20\%D0\%98\%D0\%93\%D0 \%A0.pdf (accessed: 07.04.2020). (In Russian).

2. Inside the Games. Postponement of Tokyo 2020 Olympics to cost IOC $\$ 800$ million // 14.05.2020. - URL: https://www.insidethegames.biz/articles/1094252/iocannounce-tokyo-2020-cost-800-million (accessed: 15.05.2020).

3. International Olympic Committee. Olympic Agenda 2020. Implementation plan - 2016 and beyond // 110 p. - URL: https://stillmed.olympic.org/media/ Docu- 
ment\%20Library/OlympicOrg/Documents/Olympic-Agenda-2020/Olympic-Agenda2020-Implementation-Plan-2016-andBeyond.pdf\#_ga=2.129246156.1907296350.158 8568592-1444275578.1581867662 (accessed: 02.05.2020).

4. International Olympic Committee. Olympic Solidarity // URL: https://www.oly mpic.org/olympic-solidarity (accessed: 06.05.2020).

5. International Olympic Committee. Olympic Solidarity increases its support to National Olympic Committees for their preparation for and participation in Tokyo 2020 by USD 25.3 million // 24.04.2020. - URL: https://www.olympic.org/news/olympicsolidarity-increases-its-support-to-national-olympic-committees-for-their-preparation-forand-participation-in-tokyo-2020-by-usd-25-3-million (accessed: 05.04.2020).

6. Kyodo News. 札幌経費、IOCが 部負担へ (Sapporo expenses will be partially borne by IOC) // 25.04.2020. - URL: https://this.kiji.is/626463063497868385 (accessed: 11.05.2020). (In Japanese).

7. Sakata，W. オリンピックと経斉（2020年東京オリンピック・パラリンピック競支 大会厄向けた諸䊓頁) (Olympics and Economy (Challenges for the 2020 Tokyo Olympic and Paralympic Games)). - DOI: 10.11501/9880033 // 国立国会四書館 (National Diet Library). - 2016. - № 2. - P. 17-41. - URL: https://dl.ndl.go.jp/view/downloa d/digidepo_9880033_po_078103.pdf?contentNo=1\&alternativeNo= (accessed: 04.05.2020). (In Japanese).

8. Tokyo 2020 Bidding Committee. 2020年オリンピック・パラリンピック競支大会招致 活動報告書(2020 Olympic and Paralympic Games Bid Activity Report) // апрель 2014. 322 P. - URL: https:/www.2020games.metro.tokyo.lg.jp/taikaijyunbi/torikumi/sy ochi/pdf/syochihokokusyoall.pdf (accessed: 10.04.2020). (In Japanese).

9. Tokyo 2020 Organising Committee of the Olympic and Paralympic Games. 組織委員会およびその他の経費 (V4予算) (Organising Committee and Other Entities Budget (V4 Budget)) // 20.12.2019. - - URL: https://tokyo2020.org/ja/organisingcommittee/budgets/ (accessed: 18.04.2020). (In Japanese). 